\title{
High concentrations of neurotoxin in free-living marine nematodes
}

\author{
K. Kogure*, H. K. Do**, D. S. Kim, Y. Shirayama \\ Ocean Research Institute, University of Tokyo, Minamidai, Nakano, Tokyo 164, Japan
}

\begin{abstract}
High concentrations of sodium channel blockers (SCB) in free-living nematodes - Symplocostoma sp., Mesacanthion sp., Metachromadora sp. and a mixed population of other species - were confirmed using a tissue culture bioassay. These neurotoxins included tetrodotoxin (TTX) or related toxins as determined by high performance liquid chromatography. Concentrations of SCB in nematodes were comparable to those of TTX in puffer fish, which suggests that nematodes play an important role in the accumulation and transfer of TTX or related toxins in marine environments.
\end{abstract}

KEY WORDS: Sodium channel blocker $\cdot$ Nematode $\cdot$ Tetrodotoxin

\section{INTRODUCTION}

Sodium channel blockers (SCB) are a group of neurotoxins which prevent sodium influx through the sodium channels in excitable membranes. Among them, tetrodotoxin (TTX) and saxitoxin (STX) are well known. TTX causes 'puffer fish intoxication' and STX causes paralytic shellfish poisoning (PSP), which represent serious public health problems.

These neurotoxins are found in various marine organisms. TTX is distributed widely among diverse groups of animals, including crabs (Noguchi et al. 1983), octopus (Sheumack et al. 1978), ribbon worms (Miyazawa et al. 1988), trumpet shells (Narita et al. 1981), arrow worms (Thuesen et al. 1988) and others (Table 1). Some terrestrial animals also contain TTX (Wakely et al. 1966, Fuhrman 1986); however, their origins or mechanisms of accumulation are imperfectly understood.

Since the discovery of TTX-producing bacteria (Noguchi et al. 1986, Yasumoto et al. 1986), it has been hypothesized that bacteria are the sole producers of TTX in nature and that this toxin can be biomagnified

\footnotetext{
-E-mail: kogure@ori.u-tokyo.ac.jp

- Present address: Biomedical Institute, Handong University,

Pohang-si, Buk-gu, Heunghae-eup, Namsong-ri 3, Korea

in the food web. This idea is supported by the following observations. First, marine sediments usually contain high levels of SCB or TTX (Kogure et al. 1988a). Second, TTX-producing bacteria are widely distributed in marine organisms (Hwang et al. 1989, Thuesen \& Kogure 1989) and sediments (Do et al. 1990, 1991), including diverse groups of bacteria (Simidu et al. 1987). Third, toxin concentrations in puffer fishes differ between individuals, depending on the collection site and season. In addition, cultured puffer fishes usually contain low or undetectable levels of TTX (Matsui et al. 1982). But TTX gradually accumulates when puffers are fed a TTX-containing diet (Matsui et al. 1981).

This hypothesis, however, is not yet completely proven. A recent observation using immunological staining suggests that TTX may be synthesized at least in the eggs of puffer fishes (Matsumura 1995a). Similarly, the origin of STX is also still obscure. Although phytoplankton is generally regarded as a producer of STX (White 1981, Boyer et al. 1986), the presence of STX-producing bacteria has also been reported (Kodama et al. 1988). In any case, more elaborate and quantitative investigations are required for clarifying the origin and fate of $\mathrm{SCB}$ in marine environments.

If we assume that bacteria produce $\mathrm{SCB}$ or TTX which is subsequently accumulated by organisms at higher trophic levels, then especially bacterivorous an- 
Table 1. Tetrodotoxin concentrations in some marine anumals

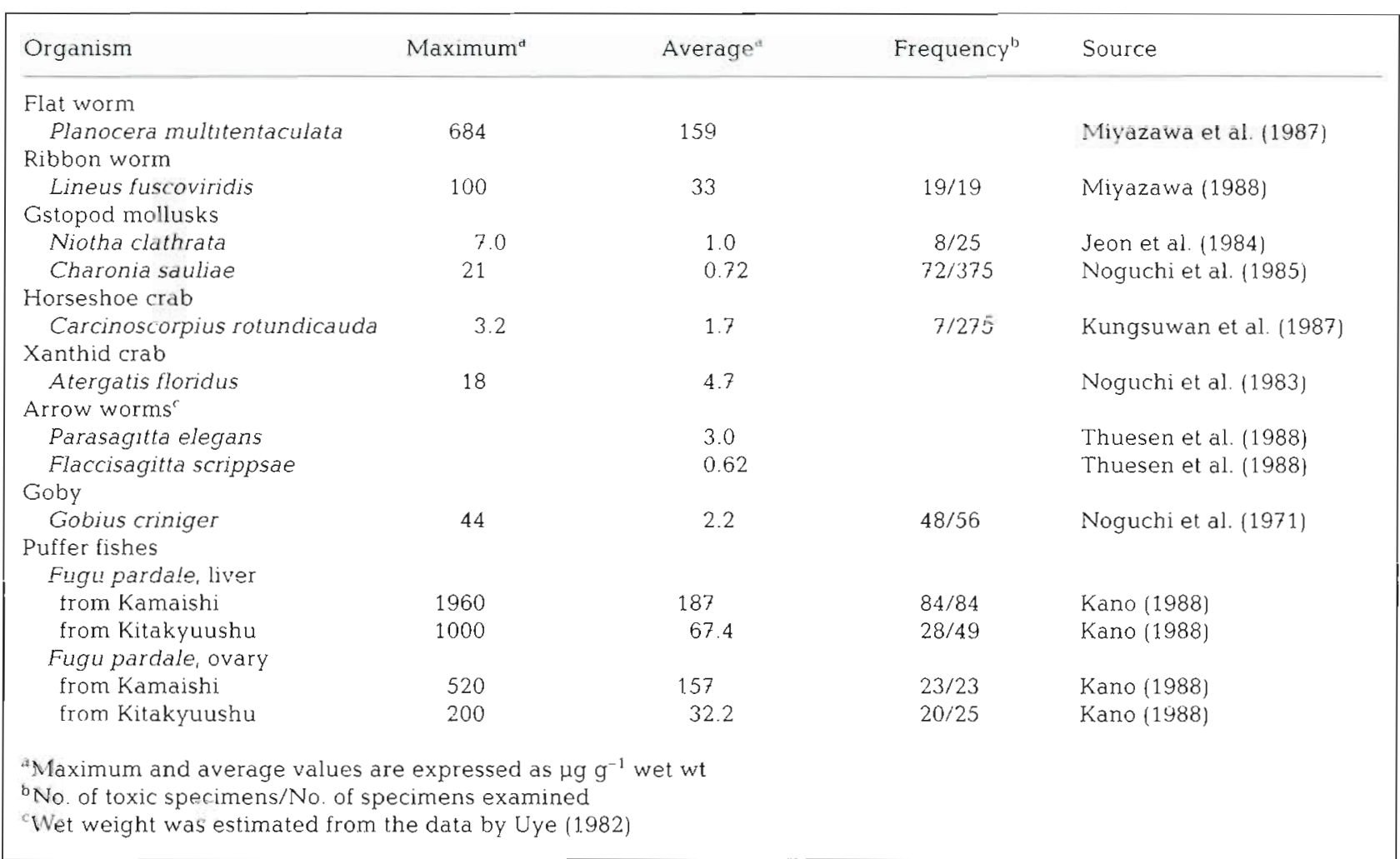

imals should contain these toxins. We have recently demonstrated the occurrence of TTX in ciliated protozoa (Do et al. unpubl.). The purpose of the present study is to examine whether free-living marine nematodes, the dominant faunal group in the meiobenthos, possess SCB. This group comprises the smallest benthic animals which can be directly handled and it may connects bacteria with organisms at higher trophic levels.

\section{MATERIALS AND METHODS}

Sampling. Sediment samples were obtained at Otsuchi Bay, Iwate Prefecture, Japan, in March 1991 using a dredge. The samples were brought back to Otsuchi Marine Research Center (OMRC), Ocean Research Institute, University of Tokyo, and the fraction passing through a $1 \mathrm{~mm}$ sieve was concentrated and used for isolating meiobenthos. Specimens were picked up using an Irwin loop under a binocular. The following 3 species of free-living nematodes were readily identified and treated separately: Symplocostoma sp., Mesacanthion sp., and Metachromadora sp. Other species of nematodes were pooled and treated as a single sample. The number of specimens collected are shown in Table 2 . The volume of nematodes was determined after the method of Price \& Warwick
(1980). The wet weight was calculated from the body mass assuming that specific density of nematodes is 1.13 (Wieser 1960).

Toxin extraction. The toxins were extracted at OMRC on the day of collection. Samples were homogenized, mixed with $0.1 \%$ acetic acid, and heated in boiling water for $20 \mathrm{~min}$. The supernatant was obtained by centrifugation $(7000 \times g, 15 \mathrm{~min})$ and filtrated through a charcoal column and a SEP-PAK C18 cartridge as described by Hamasaki et al. (1994). The resultant solution was freeze-dried and reconstituted in a small amount of distilled water.

Tissue culture bioassay. Samples were analyzed by tissue culture bioassay using the mouse neuroblastoma cell line Neuro 2A (Kogure et al. 1988b). In brief, an alkaloid toxin, veratridine causes sodium influx and subsequent death in the presence of ouabain, but SCB antagonizes this effect and enables the cells to continue growing. The relative number of viable cells correlates with the concentration of $\mathrm{SCB}$, and we estimated the toxicity level of the samples from this correlation by using TTX as a standard. A preliminary assay was first conducted to roughly estimate the toxin concentration. Then triplicate assays were run for each sample, and the result is shown as an average value of these 3 assays. At least 200 neuroblastoma cells were counted for each assay to determine the viability. 
High-performance liquid chromatography (HPLC). Samples which showed the presence of SCB were further analyzed by ion-paired reverse phase HPLC to identify TTX and its analogs according to the methods of Yasumoto \& Michishita (1985). The system and analytical conditions were the same as described in a previous paper (Hamasaki et al. 1994).

\section{RESULTS AND DISCUSSION}

The occurrence of SCB in free-living nematodes was confirmed by the tissue culture bioassay method. The concentrations were estimated from the relative number of viable cells (Table 2). SCB content per individual varied by about 1 order of magnitude.

For comparison, Table 1 gives examples of the toxin contents in various marine animals reported to possess TTX. Except for arrow worms, all quantitative measurements were done by mouse assay (Kawabata 1978), and 1 mouse unit (MU) was calculated as $200 \mathrm{ng}$ TTX in this table. As for puffer fish, TTX in the liver and ovary of specimens from 2 areas in Japan are shown. These 2 organs usually contain the highest levels of TTX. Among benthic animals, ribbon worms Lineus fuscoviridis and flat worms Planocera multitentaculata had the highest TTX levels. The maximum value from the latter species was found in the oviducts. As for other benthic organisms, average weight-specific toxicities were on the order of $1 \mu^{g^{-1}}$ wet wt.

We calculated wet-weight-specific toxin levels of nematodes (Table 2), assuming $5 \mathrm{nl}$ body volume for specimens in the mixed species group. Because this is rather an overestimate, values shown in the table should be conservative ones. Mesacanthion sp. and the mixed-species nematodes contained more TTX than puffer fish from Kitakyuushu. Metachromadora sp. possessed even higher toxicity.

Some remarks are necessary on this table. First, the distribution of the toxin is often sporadic, as seen in the frequency values in Table 1. Even among those speci- mens containing toxins, the toxin concentration differs greatly within species, individuals and organs. In the present investigation, however, we were technically unable to detect such variation among nematode individuals, because the analytical methods currently available are not sensitive enough. Immunostaining using monoclonal antibody for TTX seems to be the most promising approach (Matsumura 1995b).

Secondly, the standard mouse assay and our tissue culture bioassay give essentially the same results (Jellet et al. 1992), unless some unknown components in our samples were suppressing the function of either veratridine or ouabain. We used the tissue culture bioassay mainly because it is about 1000 times more sensitive than the mouse assay. However, both are unable to differentiate particular toxins from the SCB mixtures. Therefore, values in these tables include neurotoxins other than TTX. In order to determine the contribution of TTX to total toxicity, we analyzed the samples with HPLC. Fig. 1 shows a chromatogram of the mixed-species nematodes sample. A single peak corresponding to the retention time of a standard TTX was seen. These peaks were also obtained from other nematode species samples (data not shown). TTX contents were calculated from the peak height (Table 2). However, some caution is necessary in interpreting these data. The analysis by HPLC alone is not fully satisfactory as a chemical confirmation of TTX. In fact, we often observed peaks whose retention times were slightly shorter than that of TTX. Complete chemical analyses for both TTX and other SCBs still remain to be accomplished. Nevertheless, our results clearly indicate that high concentrations of SCB occur in nematodes. The HPLC analyses indicate that the contribution of TTX or its analogues to total toxicity could be up to $30 \%$.

In a previous paper, we reported a high concentration of SCB in marine sediment from Tokyo Bay and open ocean floor (Kogure et al. 1988a) On average, marine sediments (surface to about $20 \mathrm{~cm}$ depth) contain $45 \mathrm{ng}$ of $\mathrm{SCB} \mathrm{g} \mathrm{g}^{-1}$ or $68 \mathrm{ng} \mathrm{cm}^{-3}$ (assuming a value

Table 2. Amount of SCB and TTX in free-living nematodes

\begin{tabular}{|c|c|c|c|c|c|c|c|c|}
\hline \multirow[t]{2}{*}{ Organism } & \multirow[t]{2}{*}{$n$} & \multicolumn{2}{|c|}{ Wet weight } & \multicolumn{3}{|c|}{$\mathrm{SCB}^{\mathrm{d}}$} & \multicolumn{2}{|c|}{ TTX } \\
\hline & & $\begin{array}{c}\text { Mean } \\
\left(\mu \text { ind }^{-1}\right)\end{array}$ & $\begin{array}{l}\text { Total } \\
\text { (mg) }\end{array}$ & $\begin{array}{l}\text { Total } \\
\text { (ng) }\end{array}$ & $\begin{array}{c}\text { Per ind } \\
\text { (ng) }\end{array}$ & $\begin{array}{c}\text { Per wet wt } \\
\left(\mu \mathrm{Hg} \mathrm{g}^{-1}\right)\end{array}$ & $\begin{array}{l}\text { Total } \\
\text { (ng) }\end{array}$ & $\begin{array}{l}\text { Per und. } \\
\text { (ng) }\end{array}$ \\
\hline Symplocostoma sp. & 381 & 47.2 & 18.0 & 430 & 1.1 & 23.9 & 130 & 0.34 \\
\hline Mesacanthionsp. & 298 & 36.0 & 10.7 & 1050 & 3.5 & 98.1 & 84 & 0.28 \\
\hline Metachromadora sp. & 174 & 6.89 & 1.20 & 650 & 3.7 & 542 & 32 & 0.18 \\
\hline Others & 1975 & $5.65^{c}$ & 11.2 & 880 & 0.45 & 78.6 & 140 & 0.071 \\
\hline \multicolumn{9}{|c|}{ Measured by high-performance liquid chromatography (HPLC). This includes TTX analogues } \\
\hline
\end{tabular}




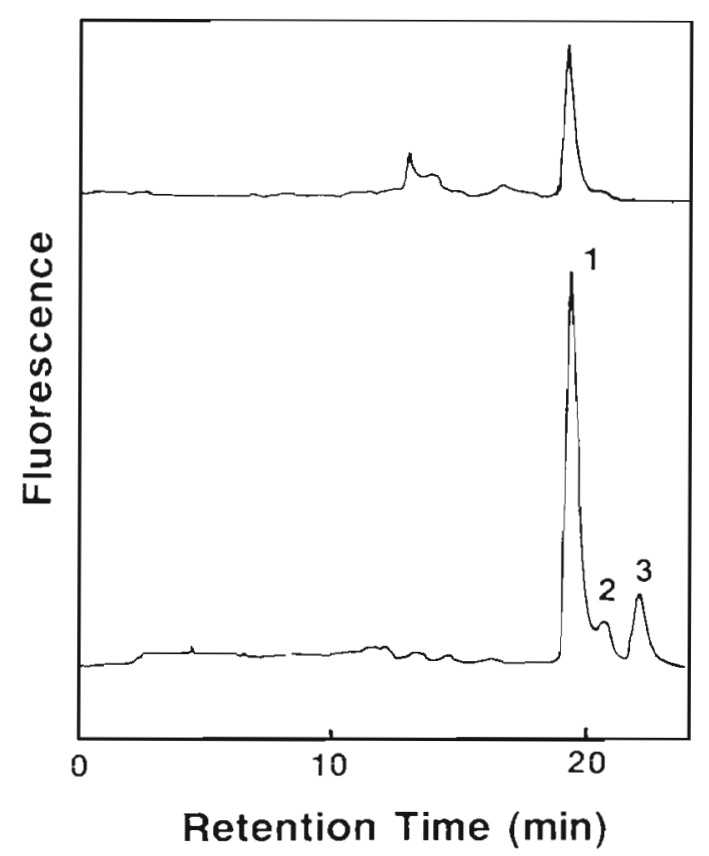

Fig. 1. High-performance liquid chromatograms of the mixedspecies nematodes sample. The upper line shows the mixedspecies sample; the lower shows the standard. (1) TTX (2) $_{4}-$ epi-TTX; (3) anhydro-TTX

of 1.5 for the specific density of the sediment). We were unable to determine in which part of the sediment $\mathrm{SCB}$ is actually located. The density of nematodes in Otsuchi Bay (Kim \& Shirayama in press) varied from 16.8 to $121 \mathrm{~cm}^{-2}$ with the maximum in March. Based on these data and Table 2, nematodes may account for 1 to $8 \%$ of total SCB in the top $10 \mathrm{~cm}$ of marine sediment. It is noteworthy that nematodes constitute 3 to $15 \%$ of the meiobenthos in the sediment of this experimental area. If $\mathrm{SCB}$ is also present in meiobenthos other than nematodes, a considerable part of the SCB in sediment may turn out to be present in these animals. On the other hand, considering the data from laboratory cultures, toxins in bacterial populations do not seem to constitute a significant proportion of those marine sediment.

There are several possible explanations for the origin of SCB-like neurotoxins in nematodes. First, SCB may be supplied as food and subsequently accumulated in the body of nematodes. Second, it may be synthesized by the animal itself. Third, nematodes may convert the precursor molecule supplied by other living organisms. The toxins may then be used as venom (Sheumack et al. 1978, Thuesen et al. 1988), for defense and/or as a more effective predation mechanism, or for unknown physiological reason. Of the 3 species of nematode we studied, Symplocostoma sp. is a herbivore, Mesacanthion sp. a carnivore and Metachromadora sp. a omni- vore (Kim \& Shirayama in press). If nematodes use toxins as venom, Mesacanthion sp. is expected to possess the highest concentration of SCB. In our results, however, toxin concentration in omnivores were 5 times greater than in carnivores. In addition, herbivores had the lowest concentrations of toxins. These results support the first explanation for the origin of SCB in nematodes, i.e. accumulation of neurotoxin through the food web. If a bacterium contains $10^{-17} \mathrm{~g} \mathrm{SCB}$, roughly at least $10^{8}$ cells must be eaten by a nematode to reach its toxin concentration. The total weight of $10^{8}$ bacterial cells roughly corresponds to that of 1 nematode. Because 1 bacterivorous nematode may consume $10^{5}$ to $10^{6}$ cells h$^{-1}$ (Tietjen 1980, Shirayama 1991), this is a realistic value. In order to verify this hypothesis, however, further experimental observations using quantitative analyses and a physiological approach for these nematode species will be required. On the other hand, to our knowledge, there are no observations or data which support the second and third hypotheses.

In conclusion, high levels of SCB were found to occur in marine nematodes, supporting the idea that $\mathrm{SCB}$ are produced mainly by microorganisms and are biomagnified through the food web. Further chemical characteristics of these toxins and the mechanism of toxification are now being investigated.

\section{LITERATURE CITED}

Boyer GL, Sullivan JJ, Andersen RJ, Taylor FJR, Harnson PJ, Cembella AD (1986) Use of high-performance liquid chromatography to investigate the production of paralytic shellfish toxins by Protogonyaulax spp. in culture. Mar Biol 93:361-369

Do HK, Kogure K, Imada C, Noguchi T, Ohwada K, Simidu U (1991) Tetrodotoxin production of actionomycetes isolated from marine sediment. J Appl Bacteriol 70:464-468

Do HK, Kogure K, Simidu U (1990) Identification of deep-sea sediment bacteria which produce tetrodotoxin. Appl Environ Microbiol 56:1162-1163

Fuhrman FA (1986) Tetrodotoxin, tarichatoxin, and chiriquitoxin: historical perspectives. Ann NY Acad Sci 479:1-14

Hamasaki K, Kogure K, Noguchi T, Shida Y, Ohwada K (1994) Tetrodotoxin in sinking particles from coastal waters. Mar Biol 11.8:761-765

Hwang DF, Arakawa $O$, Saito $T$, Noguchi $T$, Simidu $U$, Tsukamoto K, Shida Y, Hashimoto K (1989) Tetrodotoxinproducing bacteria from the blue ringed octopus Octopus maculosus. Mar Biol 100:327-332

Jellett JF, Marks LJ, Stewart JE, Dorey ML, Watson-Wright W. Lawrence JF (1992) Paralytic shellfish poison (saxitoxin family) bioassays: automated endpoint dtermination and standardization of the in vitro tissue culture bioassay, and comparison with the standard mouse bioassay. Toxicon 10: $1143-1156$

Jeon JK, Narita $H$, Nara $M$, Noguchi $T$, Maruyama J, Hashimoto K (1984) Occurrence of tetrodotoxin in a gastropod mollusk 'araregai', Niotha clathrata. Bull Jap Soc Sci Fish 50:2099-2102

Kano S (1988) Distribution of tetrodotoxin among vertebrates. 
In: Hashimoto $K$ (ed) Recent progress in research on tetrodotoxin. Koseisha-Koseikaku, Tokyo, p 32-44

Kawabata T (1978) Assay method for tetrodotoxin. In: Food hygiene examination manual, Vol 2. Japan Food Hygiene Association, Tokyo, p 232-240.

Kim D, Shirayama X (1996) Seasonal fluctuation of meiobenthos inhabiting subtidal coarse sand in Otsuchi Bay with special reference to free-living nematodes. Benthos Res (in press)

Kodama M, Ogata T, Sato S (1988) Bacterial production of saxitoxin. Agric Biol Chem 52:1075-1077

Kogure K, Do HK, Thuesen EV, Nanba K, Ohwada K, Simidu $U$ (1988a) Accumulation of tetrodotoxin in marine sediment. Mar Ecol Prog Ser 45:303-305

Kogure K, Tamplin ML, Simidu U, Colwell RR (1988a) A tissue culture assay for tetrodotoxin, saxitoxin and related toxins. Toxicon 26:191-197

Kungsuwan A, Nagashıma Y, Noguchi T, Shida Y, Suvapeepan S, Suwansakopnkul P, Hashimoto K (1987) Tetrodotoxin in the horseshoe crab Carcinoscorpius rotudicauda inhabiting Thailand. Bull Jap Soc Sci Fish 53:261-266

Matsui T. Hamada S, Konosu S (1981) Difference in accumulation of puffer fish toxin and crystalline tetrodotoxin in the puffer fish, Fugu rubripes rubripes. Bull Jap Soc Sci Fish 47:535-537

Matsui T, Sato H, Hamada S, Shimizu C (1982) Comparison of toxicity of the cultured and wild puffer fish Fugu niphobles. Bull Jap Soc Sci Fish 48:253

Matsumura K (1995a) Tetrodotoxin as a pheromone. Nature 378:563-564

Matsumura K (1995b) A monoclonal antibody against tetrodotoxin that reacts to the active group for the toxicity Eur J Pharmacol 293:41-45

Miyazawa K (1988) Distribution of tetrodotoxin among Arthropoda, Plathelminthes, and Nemertinea. In Hashimoto K (ed) Recent progress in the research on tetrodotoxin. (Suisangaku Series 70). Kouseisha-Kouseikaku, Tokyo, p 53-64

Miyazawa K, Higashiyama K, Ito K, Arakawa O, Noguchi $T$, Shida Y, Hashimoto K (1988) Tetrodotoxin in two species of ribbon worm. Lineus fuscaridis and Tubulanus punstatus. Toxicon 26:867-874

Miyazawa K, Jeon JK, Noguchi T, Ito K, Hashimoto K (1987) Distribution of tetrodotoxin in the tissues of the flatworm Planocera multitentaculata (Platyhelminthes). Toxicon 25 : $975-980$

Narita $\mathrm{H}$, Noguchi $T$, Maruyama J, Ueda $Y$, Hashimoto $K$, Watanabe Y, Hida K (1981) Occurrence of tetrodotoxin in a trumpet shell, 'Boshubora', Charonia sauliae. Bull Jap Soc Sci Fish 47:935-941

Noguchi T, Jeon JK, Arakawa O, Sugita H, Deguchi Y, Shida $Y$, Hashimoto K (1986) Occurrence of tetrodotoxin and

This article was submitted to the editor anhydro tetrodotoxin in Vibrio sp. isolated from the intestines of a xanthid crab, Atergatis floridus. J Biochem 99:311-314

Noguchi T, Kao H, Hashimoto Y (1971) Toxicity of the Goby, Gobius criniger. Bull Jap Soc Sci Fish 37:642-647

Noguchi T, Sakai T, Maruyama J, Jeon JK, Kesamaru K, Hashimoto K (1985) Toxicity of a trumpet shell Charonia sauliae ('Boshubora') inhabiting along the coasts of Miyazaki Prefecture. Bull J Soc Sci Fish 54:677-679

Noguchi T, Uzu A, Koyama K, Maruyama J, Nagashima Y, Hashimoto $K$ (1983) Occurrence of tetrodotoxin as the major toxin in a xanthid crab Atergatis floridus. Nippon Suisan Gakkaishi 49:1887-1892

Price R, Warwick RM (1980) The effect of temperature on the respiration rate of mejofauna. Oecologia 44:145-148

Sheumack DD. Howden MEH, Spence I, Quinn, RJ (1978) Maculotoxin: a neurotoxin from the venome glands of the octopus Hapalochlaena maculosa identified as tetrodotoxin. Science 199:188-189

Shirayama Y (1991) Preliminary studies on the energy budget of a deep-sea menatode. La Mer 29:170-173

Simidu U, Noguchi T, Hwang DF, Shida Y, Hashimoto K (1987) Marine bacteria which produce tetrodotoxin. Appl Environ Microbiol 53:1714-1715

Thuesen EV, Kogure K (1989) Bacterial production of tetrodotoxin in four species of chaetognatha. Biol Bull 176: 191-194

Thuesen EV, Kogure K, Hashimoto K, Nemoto T (1988) Poison arrowworms: a tetrodotoxin venom in the marine phylum Chaetognatha. J Exp Mar Biol Ecol 116:249-256

Tietjen JH (1980) Microbial-meiofaunal interrelationships: a review. In: Colwell RR, Foster J (eds) Aquatic microbial ecology. Univ of Maryland Press, Washington, DC, p $335-338$

Uye S (1982) Length-weight relationships of important zooplankton from the Inland Sea of Japan. J Oceanogr Soc Jap 38:149-158

Wakely JF, Fuhrman GJ, Fuhrman FA, Fischer HG, Mosher HS (1966) The occurrence of tetrodotoxin (tarichatoxin) in amphibia and the distribution of the toxin in the organs of newts (Taricha). Toxicon 3:195-203

White AW (1981) Sensitivity of marine fishes to toxins from the red-tide dinoflgellate Conyaulax excavata and implications for fish kills. Mar Biol 65:255-260

Wieser W (1960) Benthic studies in Buzzards Bay. II. The meiofauna. Limnol Oceanogr 5:121-137

Yasumoto T, Michishita $\Upsilon$ (1985) Fluorometric detection of tetrodotoxin by high performance liquid chromatography. Agric Biol Chem 49:3077-3080

Yasumoto T, Yasumura D, Yotsu M, Michishita T, Endo A, Kotakl Y (1986) Bacterial production of tetrodotoxin and anhydrotetrodotoxin. Agric Biol Chem 50:793-795

Manuscript first received: June 13, 1995

Revised version accepted: January 23, 1996 